\title{
25 Years of Creation, Development and Implementation of Seismic Isolation in Armenia
}

\author{
Mikayel Melkumyan \\ President, Armenian Association for Earthquake Engineering, Armenia \\ Director, "Melkumyan Seismic Technologies" LLC, Armenia
}

\begin{abstract}
How to cite this paper: Mikayel Melkumyan "25 Years of Creation, Development and Implementation of Seismic Isolation in Armenia" Published in International Journal of Trend in Scientific Research and Development (ijtsrd), ISSN: 24566470, Volume-3 | Issue-3, April 2019, pp.579-586, URL: http://www.ijtsrd.co $\mathrm{m} /$ papers/ijtsrd229 83.pdf

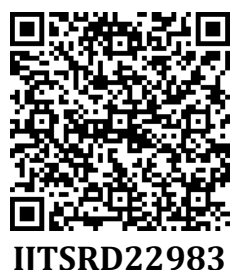

Copyright (C) 2019 by author(s) and International Journal of Trend in Scientific Research

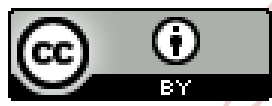
and Development Journal. This is an Open Access article distributed under the terms of the Creative Commons Attribution License (CC BY 4.0) (http://creativecommons.org/licenses/ by $/ 4.0$ )
I am proud to announce that the year of 2018 marks the $25^{\text {th }}$ Anniversary since I started to create, develop and implement seismic isolation technologies in Armenia.

It has been a hard path indeed, but with God's help and my persistence, I was able to successfully struggle my way through, overcome the conservatism, opposition and malice of state officials and of the so called "earthquake resistant construction experts". As a result, in the field of seismic isolation a small and developing country like Armenia now stands side by side with more powerful and advanced countries. Currently, by the number of seismic (base and roof) isolated buildings (more than 50) per capita Armenia is the second in the world after Japan.

In this regard, the opinion of the well-known scientist Prof. Stavros Anagnostopoulos, expressed in his interview to the Journal of the Builders Union of Armenia - Architecture and Construction, \#6(64) of June 2011, about the works performed by the author of this paper is presented: "Prof. Mikayel Melkumyan is a very well-known worldwide for his pioneering works on this technique, base isolation, which is probably the future of the earthquake protection. Prof. Melkumyan published a book with his contributions in earthquake engineering in Armenia and with all the pioneering works of base isolated buildings that he has designed here in Armenia.

Now, from my international experience I do not really know anyone else and anywhere else in the world who has made so many designs of base isolated buildings. In this respect, I think that Prof. Melkumyan has placed Armenia in one of the top countries in the world as far as application of base isolation is concerned. As the matter of fact, ifyou take into account the size of Armenia, I would imagine that maybe Armenia is in the top two to three countries where base isolation has been used so extensively. I can tell you now that among many people in the world who worked and carry our research on base isolation Mikayel is unique in the fact that he is not only doing research in base isolation but he applies it as an engineer and you cannot find that many people worldwide who combine this - generating the knowledge and also applying the knowledge; and I am in the unique position to appreciate the difficulties in taking some theoretical research results and apply them into practice and making them practically useful. This is where Mikayel has to be congratulated. I am sure that his book will be extremely useful not just in Armenia but worldwide in many countries because it is a combination of theory and practice, and most of the books that you will find in the literature on base isolation are mainly theoretical".

To commemorate this Anniversary, we have prepared posters (Table 1) describing our activities and achievements in the field of seismic isolation during the past 25 years. The information in the posters is given in Armenian, English and

Russian. We have also compiled a booklet and published it for distribution in Armenia, as well as distributed it electronically among scientists and engineers across the world. And this is all what I could do on my personal means.

It is worth noting one of the feedbacks received to the booklet from KPFF Portland Structural Dr. Jeff Diephuis, who wrote: "Congratulations! I hope that one day we begin to design with these systems in the USA as regularly as you do in Armenia. Keep up the good work".

Armenia is well-known as the only developing country where: “...the number of new applications of innovative anti-seismic techniques, especially seismic isolation, is particularly large...". "Some other countries are beginning to follow the excellent example of Armenia (...where seismic isolators are locally manufactured also for foreign markets...)"; "...an existing bank building at Irkutsk-City in Russia, retrofitted by applying the technology invented by Prof. Melkumyan in Armenia..." (Martelli et al., 2001). Another opinion on Armenia's achievements in seismic isolation expressed in (Garevski, 2010): “A greater success in application 
International Journal of Trend in Scientific Research and Development (IJTSRD) @ www.ijtsrd.com eISSN: 2456-6470

of base isolation (with isolation of a large number of buildings) was achieved in Armenia where, in addition to placement of isolators in buildings, their production was also adopted". In (Martelli et al., 2012) it is stated that: "Armenia... remains second, at worldwide level, for the number of applications of such devices per number of residents, in spite of the fact that it is still a developing country."

Thus, let me emphasize that in Armenia we have achieved significant results in the development and application of seismic isolation to a large number of buildings and in local manufacturing of about 5100 seismic isolation laminated rubber-steel bearings (SILRSBS).

Table1. Posters describing activities and achievements in the field of seismic isolation in Armenia during the past 25 years

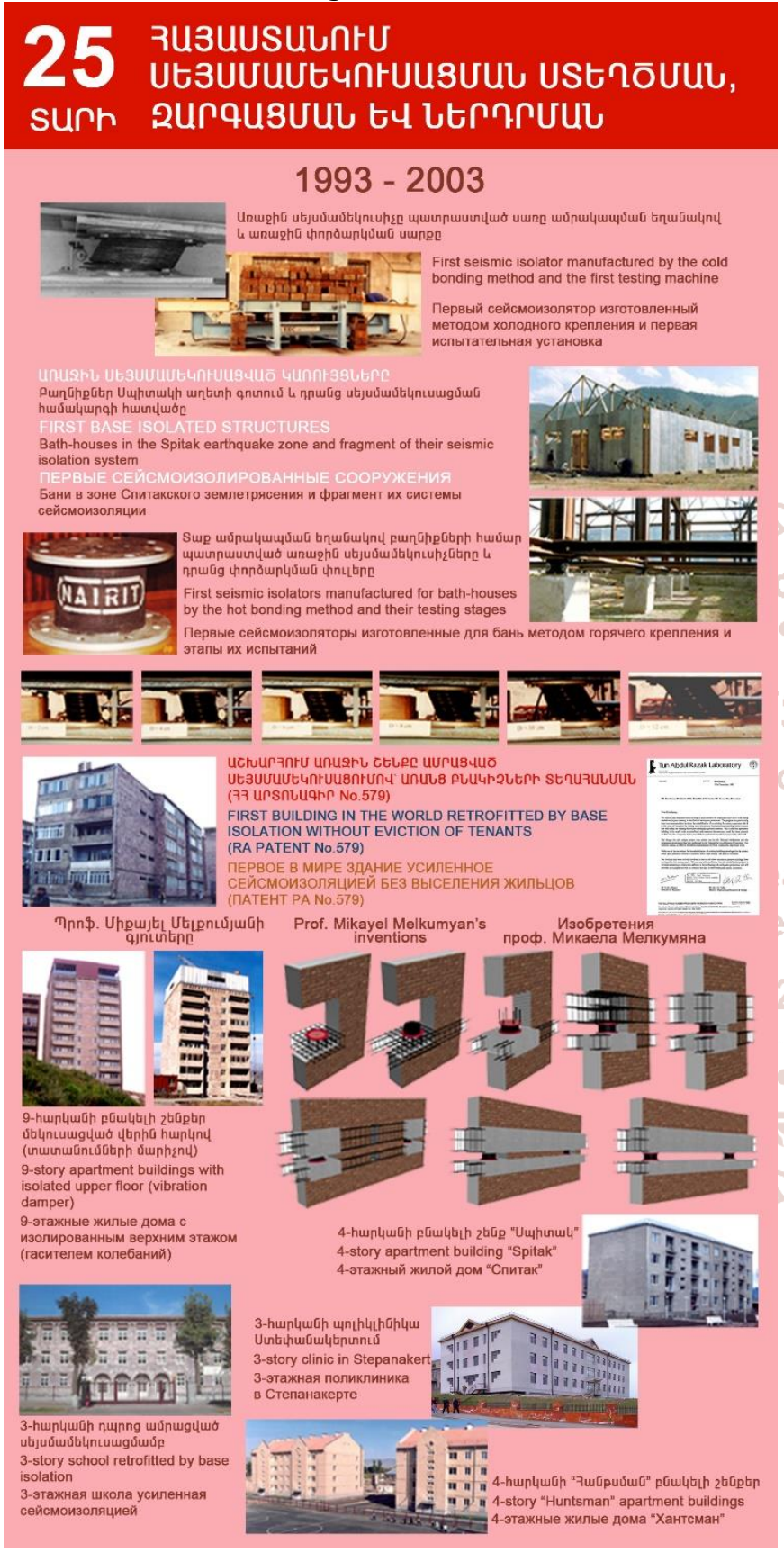

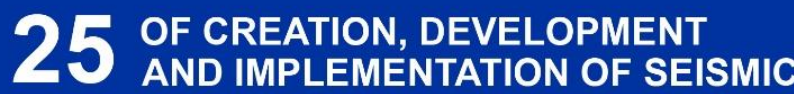 YEARS ISOLATION IN ARMENIA}

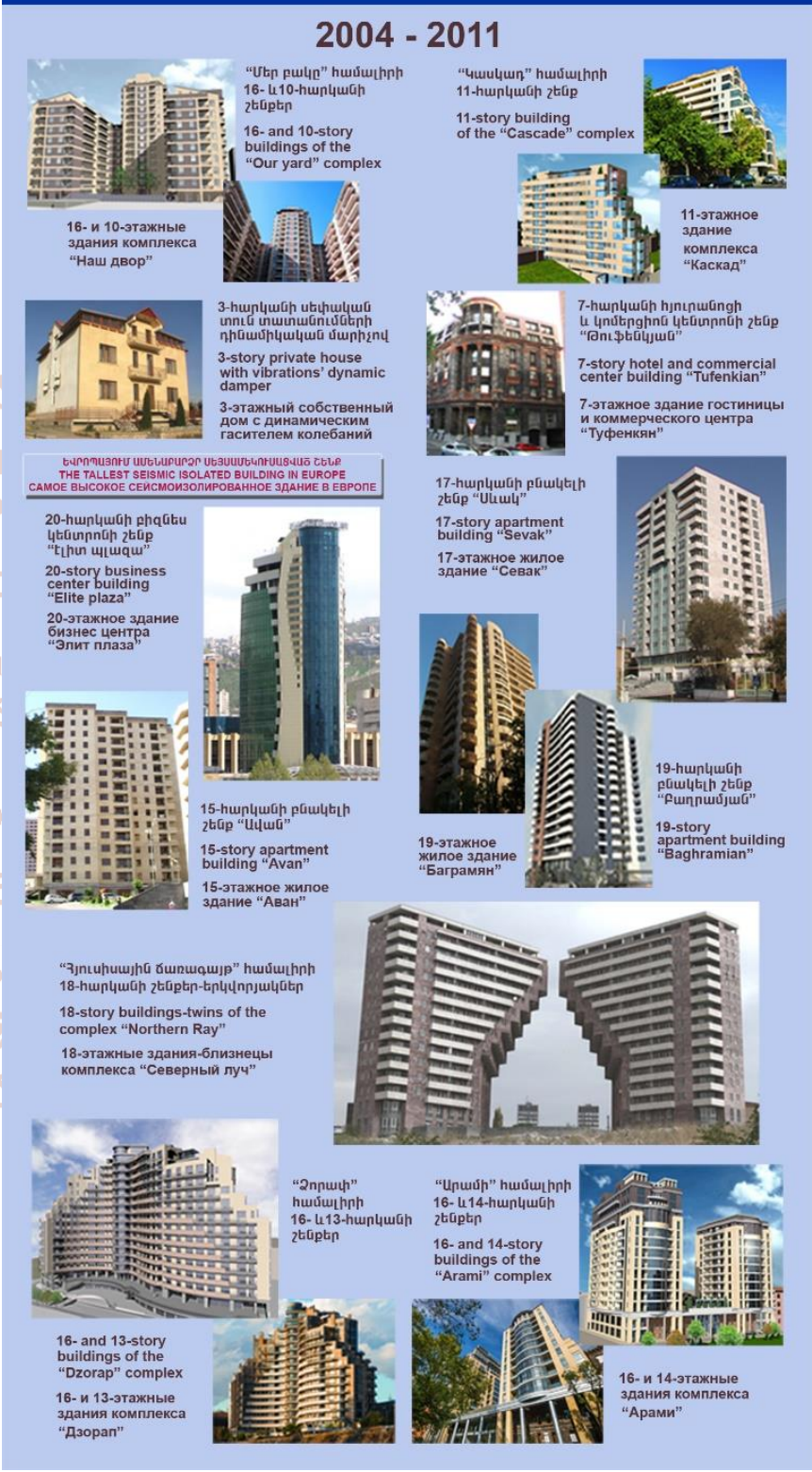

Table1. Continued 


\section{5 СОЗДАНИЯ, РАЗВИТИЯ ЛЕТ В АРМЕНИИ}

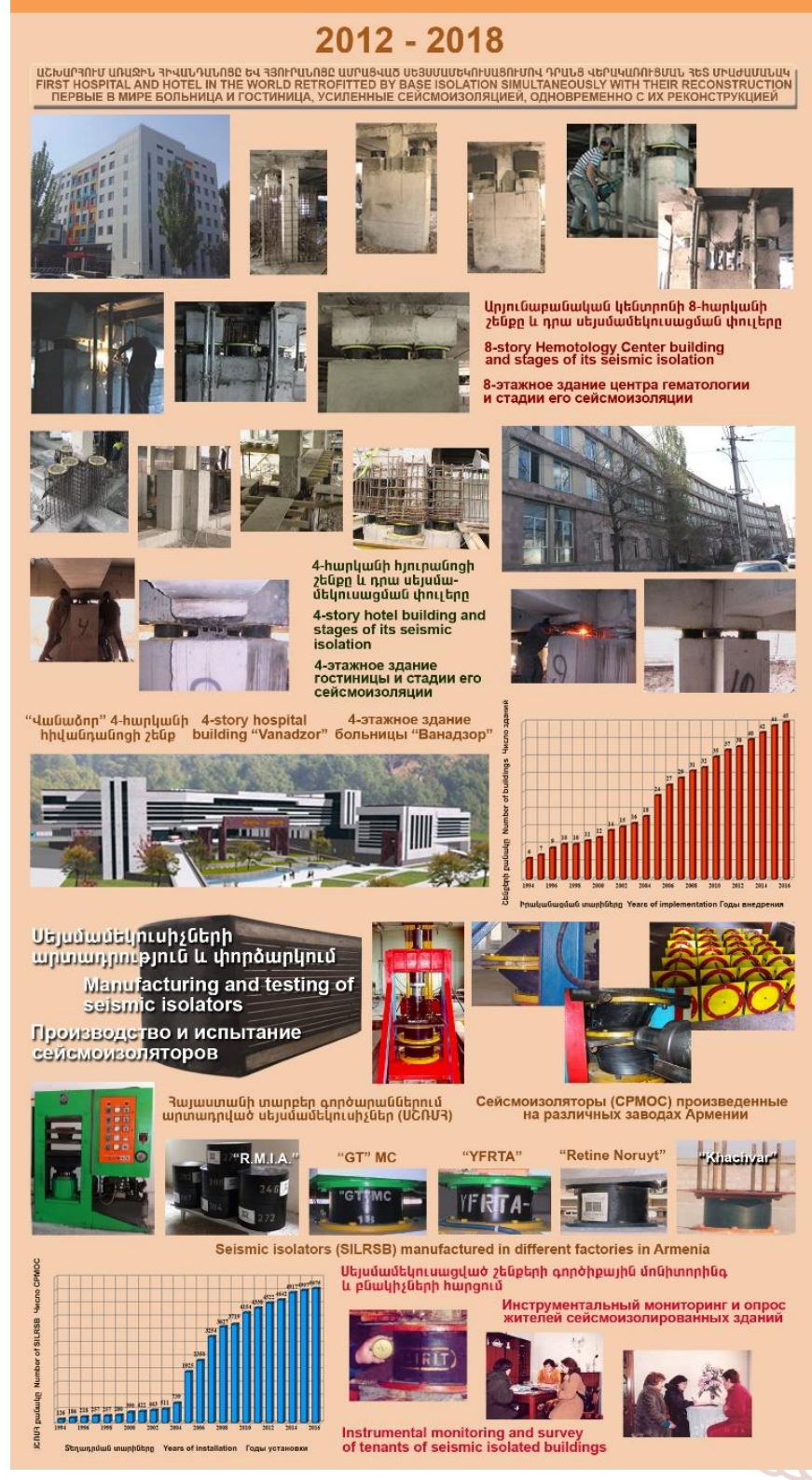

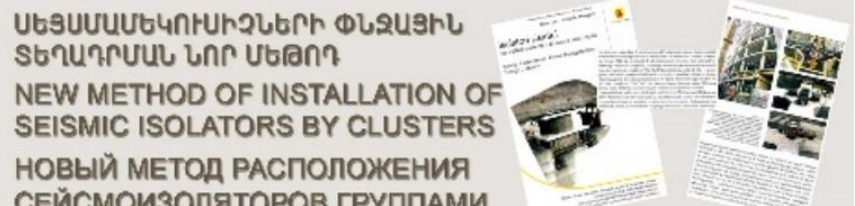
СЕЙСМОИзоЛ

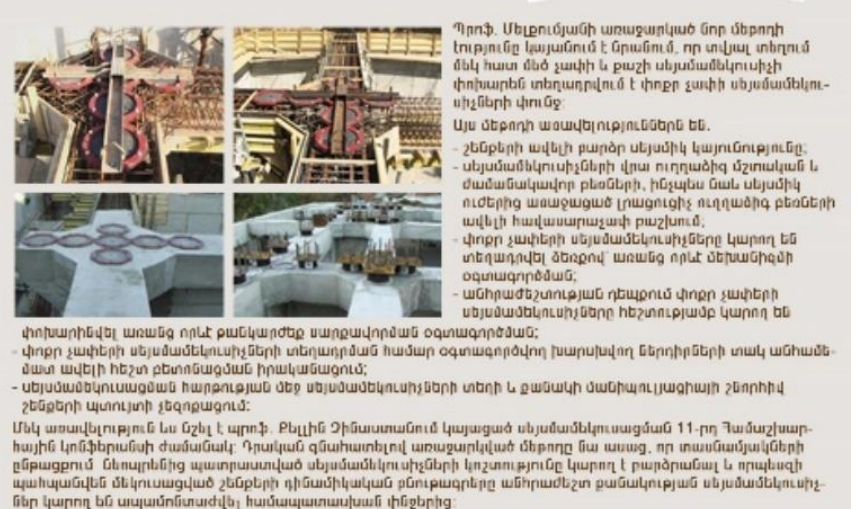

The essence of the suggested by Prot. Melkumyan Tew method is that in a given location instead of a cluster of small size seiemic isolators is installe The advantaxyes of this method are: Increased eeismic atability of the bulldinge; - more unitorm diatroution of the vertcal dead and live loads, as well as additional vertical seismic loedda on the rubber beering:; uaing sny mechanisms; - easy replacement of small bearings, it necessary. without using any oxpensive equipment. anchors and recess rings of small diameler for installation of bearings,

- neutralization of rolation of buildings by manipulation of the number and location of tearings in the seissnic
isolation plane. One more advantage was pointed out by Prot. Kally during the 11 th Word Conterences on Seismic /solation in Guangzhou, Chine. Positvely eveluating the suggeated method he mentioned that in the courae of decades the buildings the nooded number of fubber bearings can be dismantled from the relevant clusters.

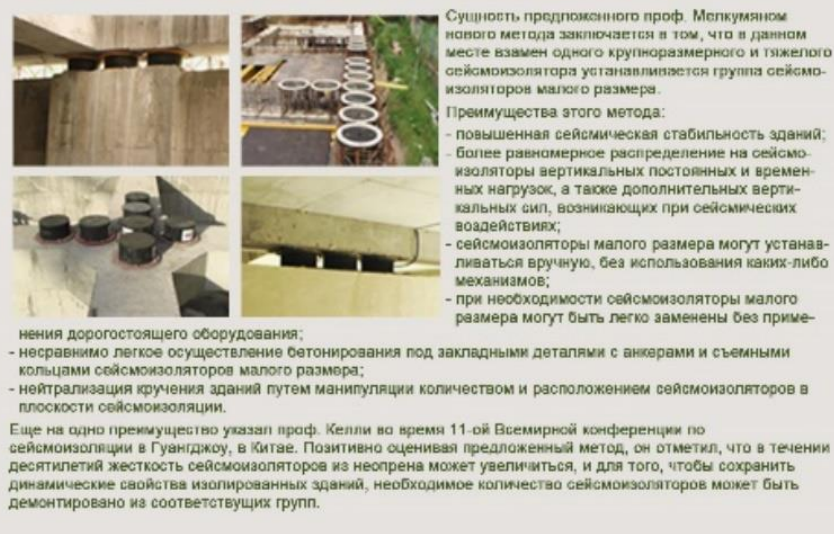

The second significant achievement is the retrofitting of existing buildings by base or roof isolation without interruption of the use of the buildings. Four buildings, namely, 5-story apartment, 3-story school, 8-story hospital and 5-story hotel were retrofitted by application of base isolation and two 9-story apartment buildings were retrofitted/protected by application of roof isolation systems. Figure 1 shows the letter sent by Director of Research Dr. C.S.L. Baker and Head of Engineering Research \& Design Dr. K.N.G. Fuller of the UK based MALAYSIAN RUBBER PRODUCER'S RESEARCH ASSOCIATION to the first President of the Republic of Armenia Mr. Levon Ter-Petrosian with congratulations and recognition of the fact that the 5-story apartment building is the first building in the world retrofitted by this technology. The letter also mentioned that: "Wide use of the technique ... offers great potential benefit to countries with a high seismic risk such as Armenia".

The reader can learn more details about this technology, as well as about roof isolation technology in (Melkumyan, 1996, 2011, 2018). 
Table1. Continued

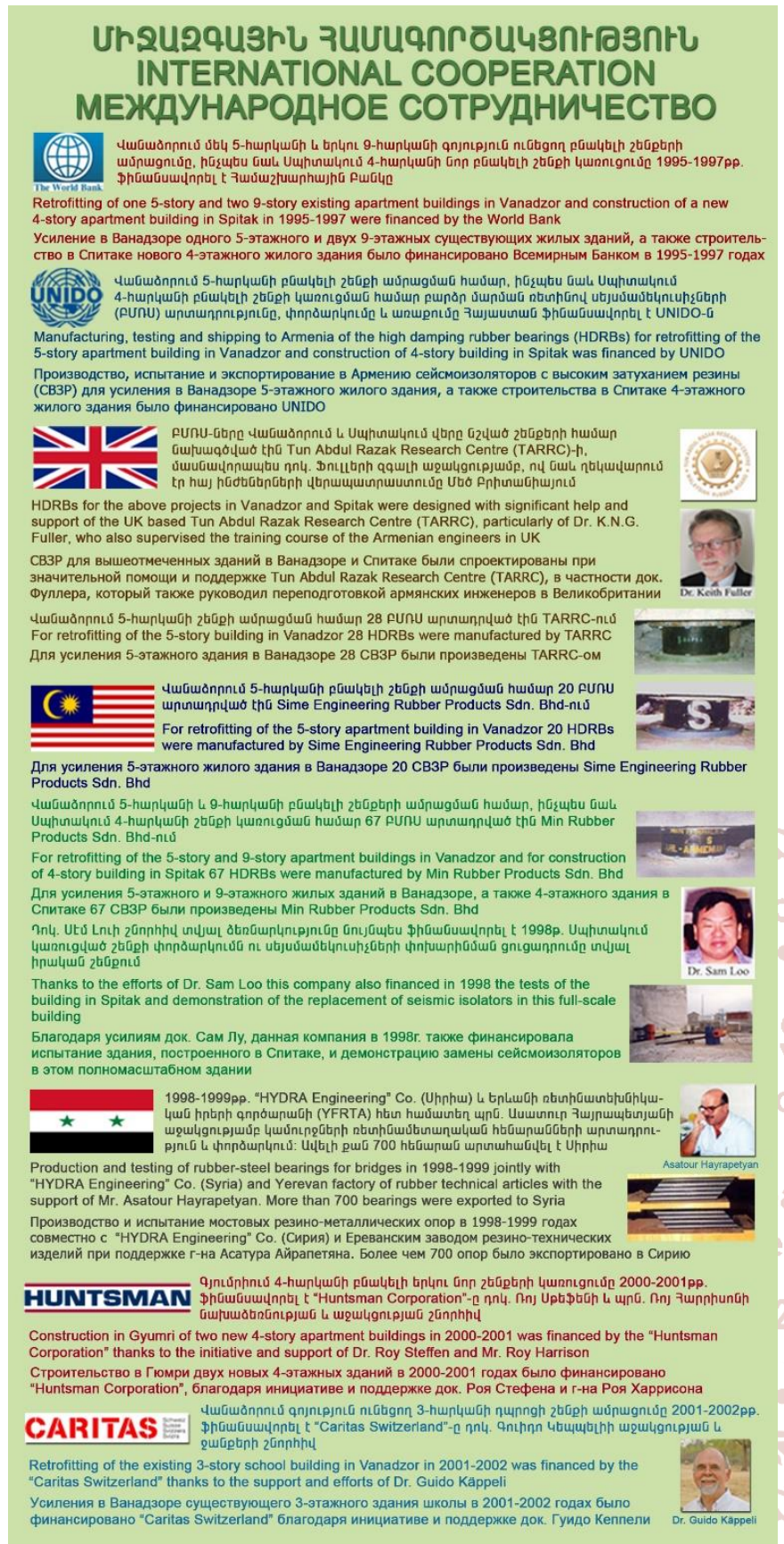

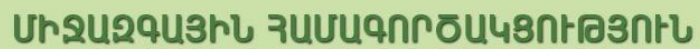 INTERNATIONAL COOPERATION МЕЖДУНАРОДНОЕ СОТРУДНИЧЕСТВО}

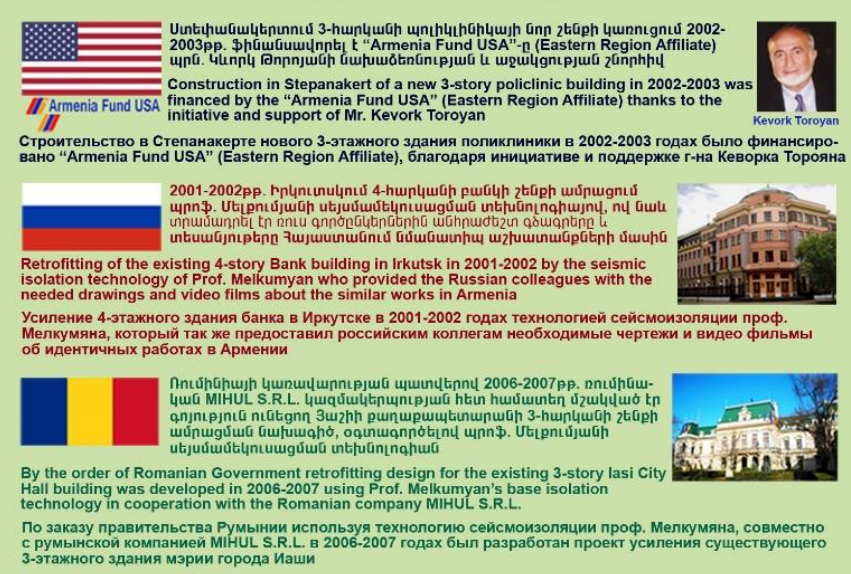

The next important achievement is the developed method of installation of SILRSBs by clusters in the seismic isolation interface. We started to extensively implement this method after 2003 by using in clusters small size rubber bearings instead of weighty large size single bearings. The advantages of this method are listed on the corresponding poster in Table 1. Many scientists and engineers who are carrying out their research and design works in the field of seismic isolation have already expressed their endorsement and support to the proposed new method. For example, Figure 2 presents the cover page of the book written by our Italian colleagues (Foti \& Mongelly, 2011) and some information from the relevant chapter of this book. It must be underlined that this method is equally applicable in both construction of new buildings and retrofitting of existing buildings with seismic isolation systems.

The reader can learn more details about this method in (Melkumyan et al., 2005, Melkumyan \& Hovhannisyan, 2006, Melkumyan, 2013). 
Table1. Continued

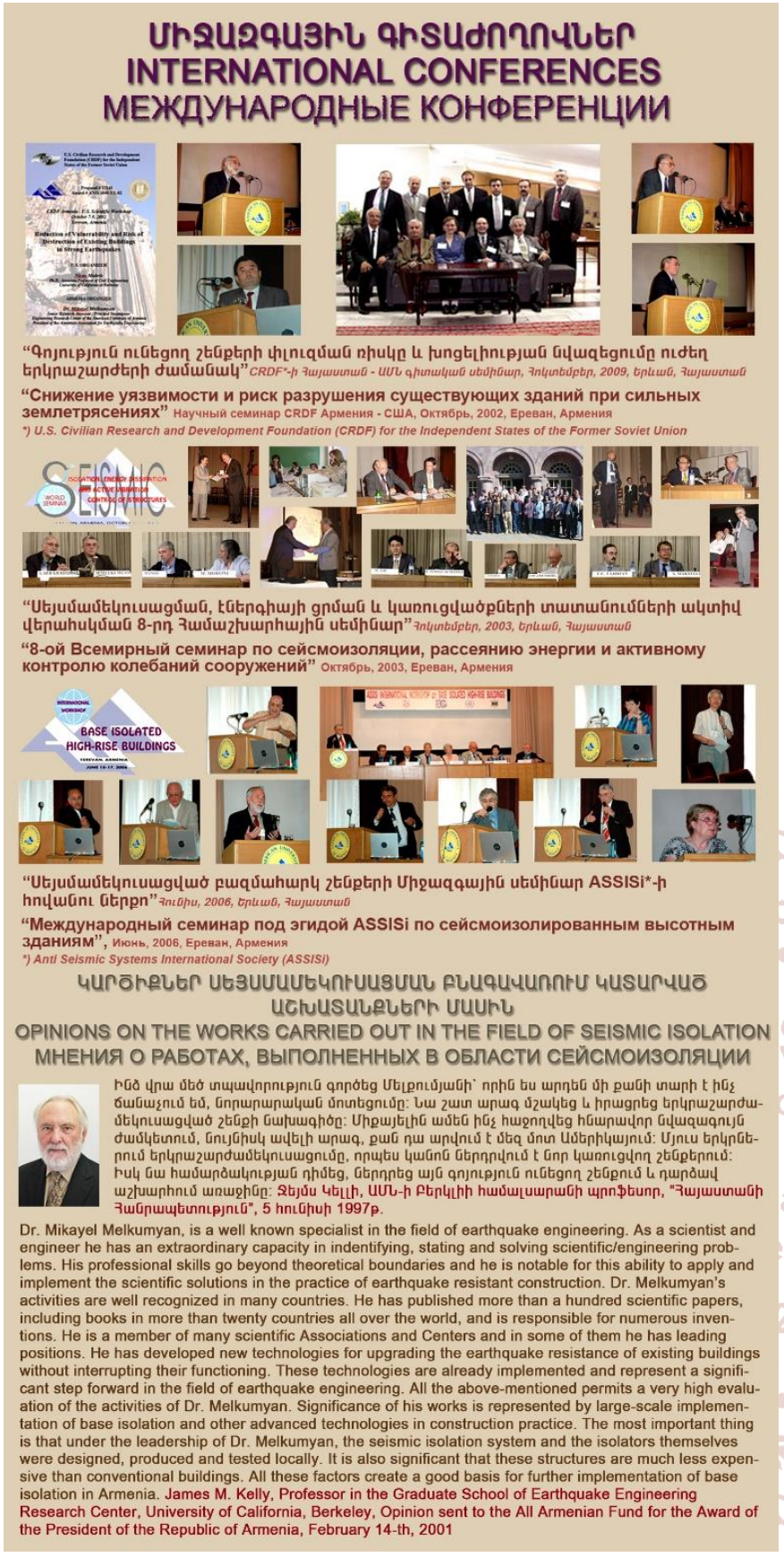

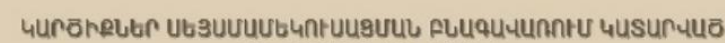
UCluLSULELERh UUURl

OPINIONS ON THE WORKS CARRIED OUT IN THE FIELD OF SEISMIC ISOLATION МНЕНИЯ О РАБОТАХ, ВЫПОЛНЕННЫХ В ОБЛАСТИ СЕЙСМОИЗОЛЯЦИИ

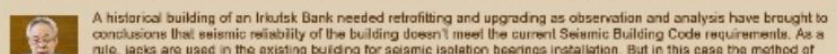

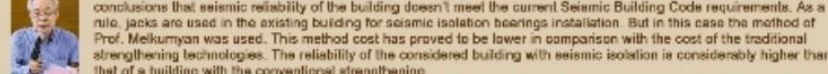

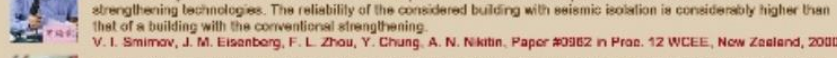

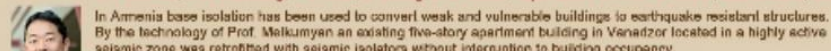

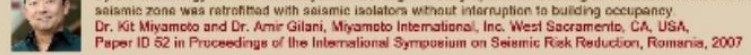

Antill

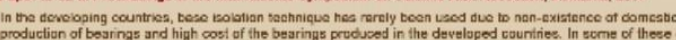

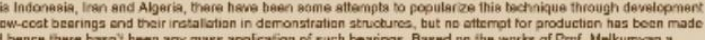

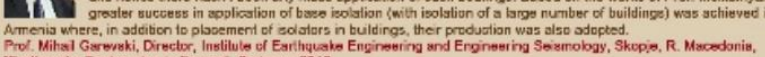

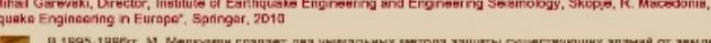

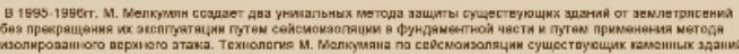
(3)

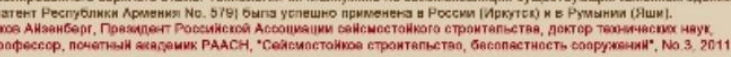

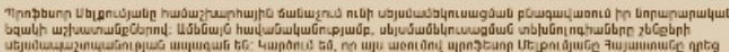

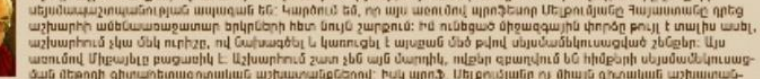

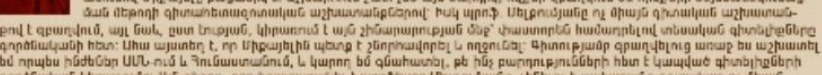

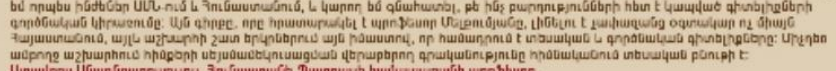

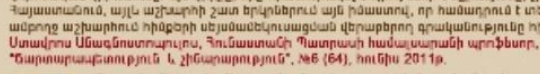

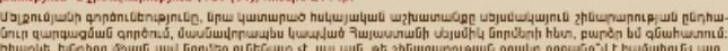

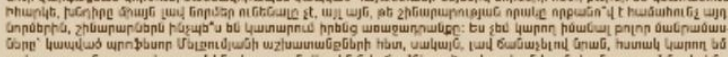

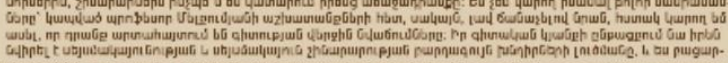

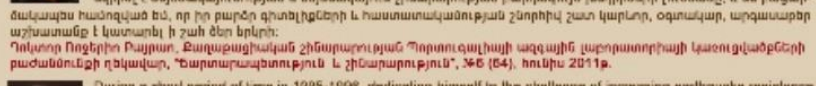

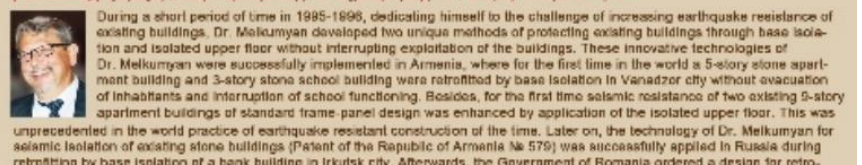

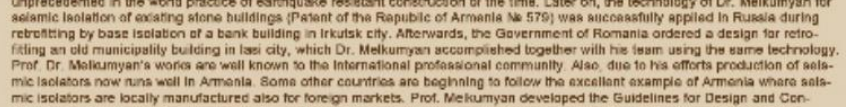

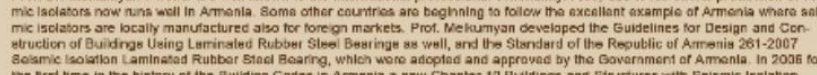

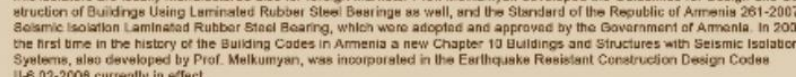

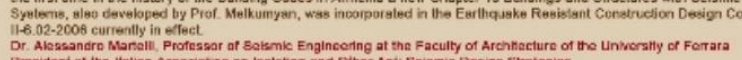

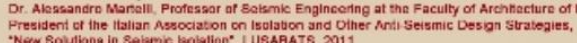

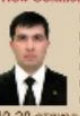

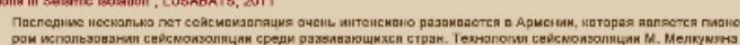

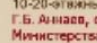

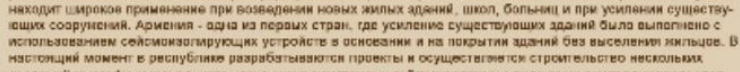

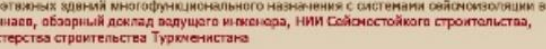

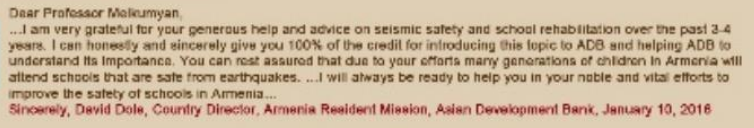

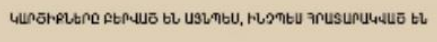

Another substantial achievement is the development of several normative documents which allow to widely design and implement the seismic isolation systems in Armenia. These documents include the developed by me Chapter 10 - "Buildings and Structures with Seismic Isolation Systems". This chapter is currently in force in the new edition of the Armenian Seismic Code RABC II-6.02-2006 adopted by the Government of Armenia. By my efforts and editing this Code was translated into English using the funds provided by the Armenian Association for Earthquake Engineering. Translated version is shown in the poster given in Table 1.

Together with that I also developed two other normative documents, namely, the "Guidelines for Design and Construction of Buildings with Application of Laminated Rubber Steel Bearings" and the Standard of the Republic of Armenia HST 261-2007 "Seismic Isolation Laminated Rubber Steel Bearing" (Fig. 3). They were adopted in 2007 by the Armenian Ministry of Urban Development. 


\section{Tun Abdul Razak Laboratory}

A unit of the

MALAYSIAN RUBBER RESEARCH AND DEVELOPMENT BOARD

YOUR REF:

OUR REF:

KNGF/SGL

11th December 1995

His Excellency President of the Republic of Armenia, Mr. Levon Ter-Petrosian

Your Excellency,

We wish to take this opportunity to bring to your attention the important innovative work being carried out in your country in the field of earthquake protection. The project that particularly deserves commendation involves the rehabilitation of an existing five-storey apartment block in the town of Vanadzor by cutting away the present foundation and inserting rubber mounts that will isolate the building from future earthquake ground motions. This is the first apartment building in the world to be so retrofitted, and moreover the necessary work has been planned so that only the occupants of the ground floor apartments need to be temporarily rehoused.

The design for this unique project was carried out by Mr. Michael Melkumian and the subsequent development has been performed by the National Survey of Seismic Protection. Our institute wishes to offer its heartiest congratulations to those leading this important work.

Wide use of the technique for the rehabilitation of existing buildings developed in the project offers great potential benefit to countries with a high seismic risk such as Armenia.

Our institute has been actively involved in the use of rubber mounts to protect buildings from earthquakes for twenty years. We can say with confidence that the rehabilitation project in Armenia is making an important addition to the technology of earthquake protection, and will provide an example not only to Armenia but also to other earthquake-prone countries.

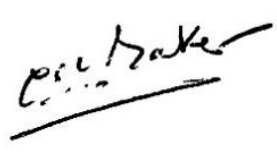

Dr. C.S.L. Baker Director of Research
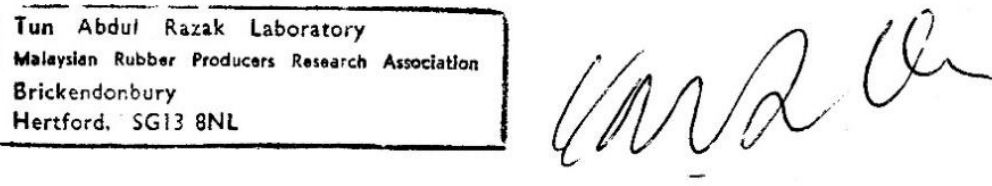

Dr. K.N.G. Fuller

Head of Engineering Research \& Design

THE MALAYSIAN RUBBER PRODUCERS' RESEARCH ASSOCIATION,

Tun Abdul Razak Laboratory, Brickendonbury, Hertford SG13 8NL, England. (Registered Office) Telephone: Hertford (STD 0992) 584966 Fax: 0992554837

All reasonable care is taken to ensure the reliability of the contents of this communication, but neither the Association nor its officers accept any legal responsibility for information or advice given or opinions expressed whether in response to specific enquiries or otherwise.

Fig. 1. The letter from “The Malaysian Rubber Producer's Research Association” addressed to the first President of the Republic of Armenia recognizing uniqueness of the project on retrofitting by base isolation of the apartment building in Vanadzor 

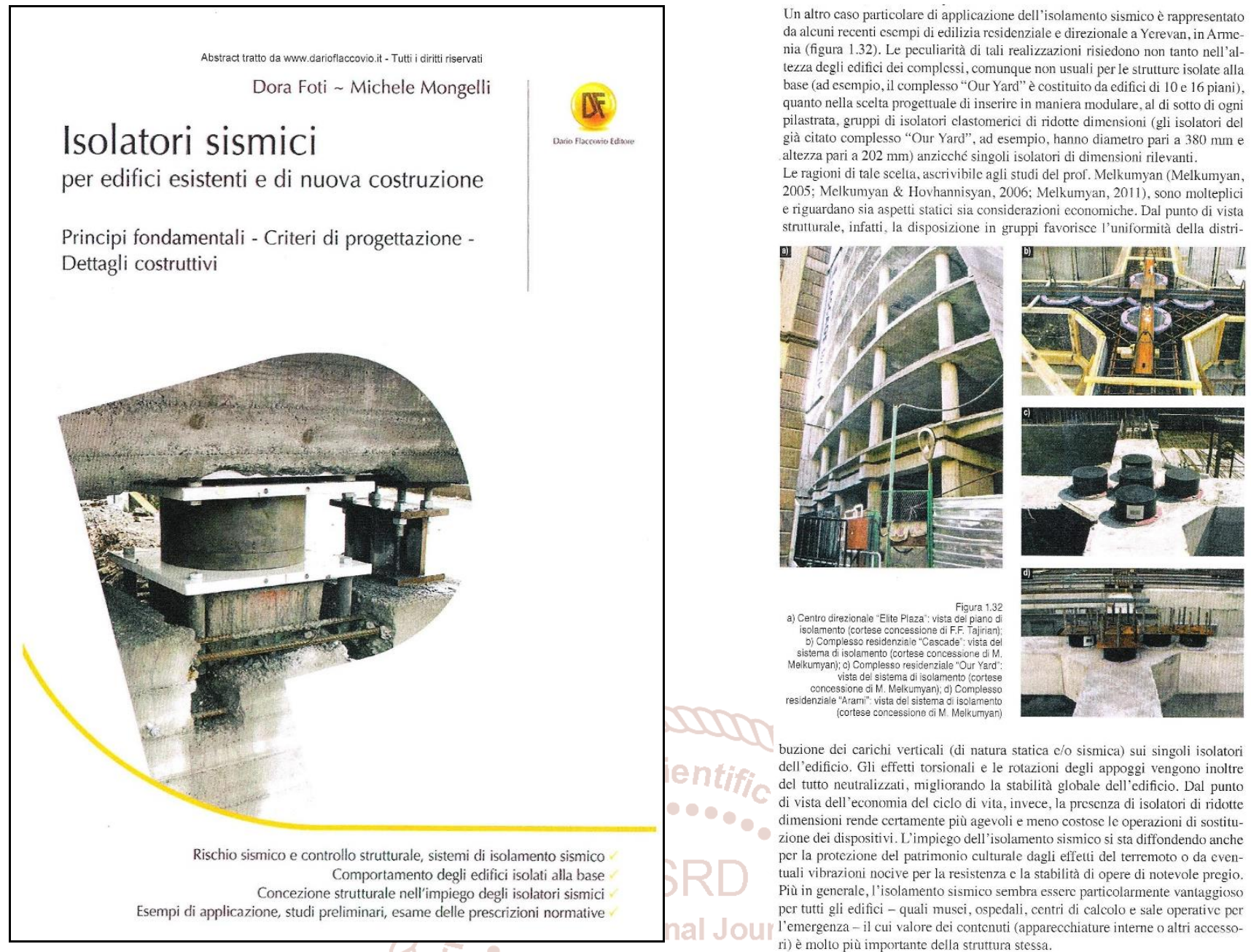

Fig.2. Example showing recognition of the proposed method on installation of small size SILRSBs by clusters in seismic isolation interface instead of weighty large size single bearings

In his opinion sent to the All Armenian Fund for the Award of the President of the Republic of Armenia on February 14-th, 2001 Prof. James Kelly, whom I consider as the pro-father of the modern seismic isolation, declares the following: "Dr. Mikayel Melkumyan, is a well-known specialist in the field of earthquake engineering. As a scientist and engineer he has an extraordinary capacity in identifying, stating and solving scientific/engineering problems. His professional skills go beyond theoretical boundaries and he is notable for this ability to apply and implement the scientific solutions in the practice of earthquake-resistant construction.

Dr. Melkumyan's activities are well recognized in many countries. He is a member of many scientific Associations and Centers and in some of them he has leading positions. He has developed new technologies for upgrading the earthquake resistance of existing buildings without interrupting their functioning. These technologies are already implemented and represent a significant step forward in the field of earthquake engineering.

Significance of his works is represented by large-scale implementation of base isolation and other advanced technologies in construction practice. The most important thing is that under the leadership of Dr. Melkumyan, the seismic isolation system and the isolators themselves were designed, produced and tested locally. It is also significant that these structures are much less expensive than conventional buildings. All these factors create a good basis for further implementation of base isolation in Armenia". 
a.

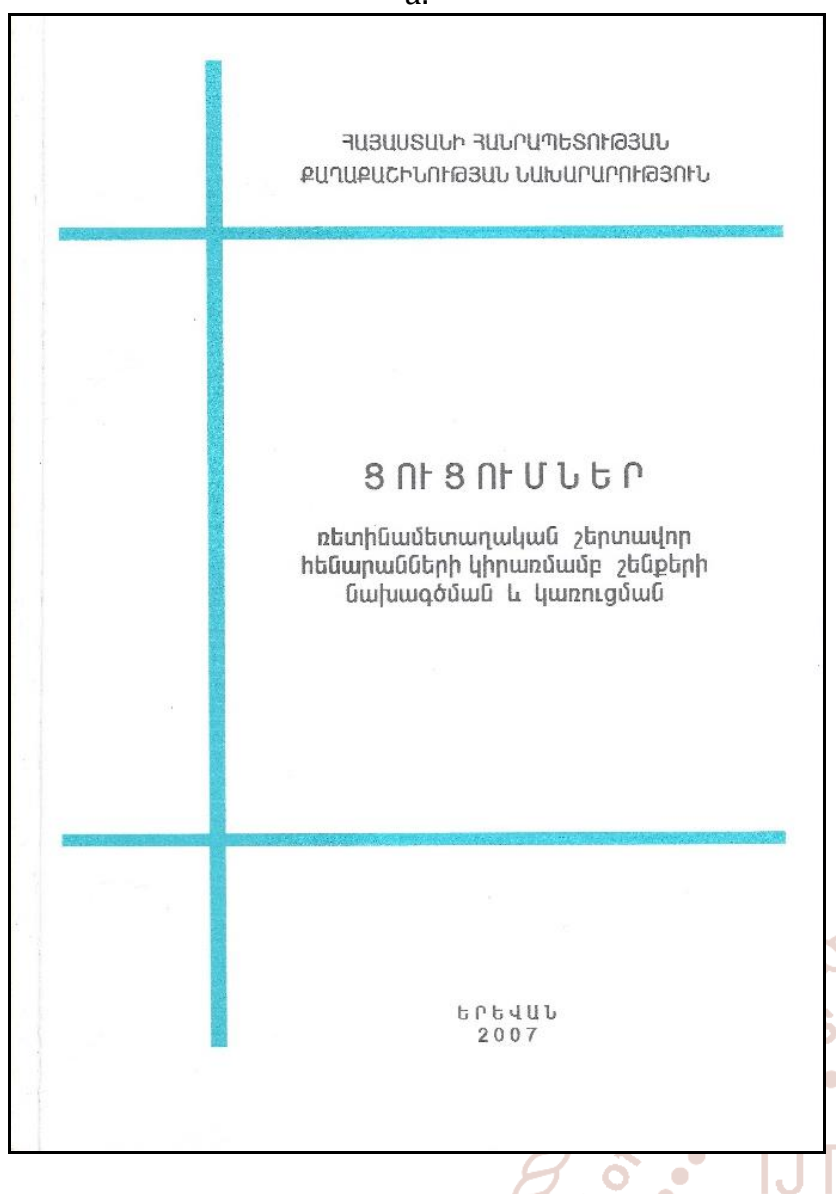

b.

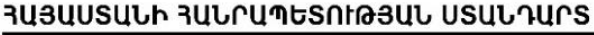

ZUS 261-2007

UtзUuUutunruusuul ctrsuчne ntshluutsunuчul ztlurul Sthulphumulu u्ujumultin

Fig. 3. Normative documents: the "Guidelines for Design and Construction of Buildings with Application of Laminated Rubber Steel Bearings" (a), and the Standard of the Republic of Armenia HST 261-2007 "Seismic Isolation Laminated Rubber Steel Bearing" (b)

I hope that sharing this information to my colleagues across the world will give them a better sense about and appreciation of what has been done so far in my country in the field of seismic isolation.

Despite many difficulties and enormous resistance, I remain committed to actively continuing my endeavors in further advancing technologies that save lives.

\section{References}

[1] Martelli, A., Forni, M., Arato, G.-B., \& Spadoni, B. (2001). Overview and Summary of the $7^{\text {th }}$ International Seminar on Seismic Isolation, Passive Energy Dissipation and Active Control of Vibrations of Structures, Preface to the Proceedings of the $7^{\text {th }}$ Int. Seminar, Assisi, Italy, i-xxxvii.

[2] Garevski, M. (2010). Development, Production and Implementation of Low-Cost Rubber Bearings, Geotechnical, Geological and Earthquake Engineering, vol.17, Earthquake Engineering in Europe. Eds - M. Garevski, A. Ansal, Springer, $411-437$.

[3] Martelli, A., Forni, M. \& Clemente, P. (2012). Recent Worldwide Application of Seismic Isolation and Energy Dissipation and Conditions for Their Correct Use, Proceedings of the $15^{\text {th }}$ WCEE, Lisbon, Portugal.

[4] Melkumyan, M. (1996). Patent of the Republic of Armenia \#579.

[5] Melkumyan, M. (2011). New Solutions on Seismic Isolation, Lusabats, Yerevan, Armenia, ISBN 978-9939-808-76-5, 2011, $280 \mathrm{p}$.

[6] Melkumyan, M. (2018). Seismic Isolation Strategies for Earthquake-Resistant Construction: Emerging Opportunities, Cambridge Scholars Publishing, UK, ISBN (10): 1-5275-1802-7, ISBN (13): 978-1-5275-1802-5, 2019, 268 p.

[7] Foti, D \& Mongelli, M. (2011). Isolatori sismici per edifice esistenti e di nuova costruzione, Dario Flaccovio Editore, (in Italian).

[8] Melkumyan, M., Gevorgyan, E., \& Hovhannisyan, H. (2005). Application of base isolation to multifunctional multistory buildings in Yerevan, Armenia, Proceedings of the $9^{\text {th }}$ World Seminar on Seismic Isolation, Energy Dissipation and Active Vibration Control of Structures, Kobe, Japan, vol.2, 119-127.

[9] Melkumyan, M., \& Hovhannisyan, H. (2006). New approaches in analysis and design of base isolated multistory multifunctional buildings, Proceedings of the First European Conference on Earthquake Engineering and Seismology, Geneva, Switzerland, paper no.194.

[10] Melkumyan, M. (2013). New approach in design of seismic isolated buildings applying clusters of rubber bearings in isolation systems, Earthquakes and Structures. An International J., vol.4, no.6, 587-606. 